Japan. J. Med. Sci. Biol., 29, 277-281, 1976

\title{
NOTES
}

\section{TRANSIENT DELAYED-TYPE HYPERSENSITIVITY INDUCED BY LIGHTLY LIPID-CONJUGATED BSA AND ITS CONVERSION INTO SUSTAINED NATURE BY CYCLOPHOSPHAMIDE TREATMENT IN GUINEA PIGS}

Injection of bovine serum albumin (BSA) heavily conjugated with dodecanoic acid, a saturated straight chain fatty acid, has been found to induce strong sustained delayed-type hypersensitivity $(\mathrm{DTH})$ in guinea pigs. DTH was specific for BSA and was not accompanied with detectable immune response to the lipid moieties (Coon and Hunter, 1973). Since it was able to induce strong DTH and no detectable antibody production without using adjuvant, this lipidconjugated BSA (D-BSA) seems to be suitable for the investigation of regulatory mechanism involved in DTH. In this paper, we will report transient DTH, which was changed into sustained DTH by treatment with cyclophosphamide, induced by a single injection of lightly conjugated D-BSA and discuss possible presence of some suppressive mechanism for DTH.

D-BSA preparations with different degrees of conjugation were obtained in manners similar to those described by Coon and Hunter (1973) and Dailey and Hunter (1974). The average number of fatty acids conjugated per BSA molecule is indicated by a subscript, e.g., $\mathrm{D}_{55} \mathrm{BSA}$.

Groups of five guinea pigs (Hartley strain, female, 350 to $500-\mathrm{g}$ weight) were injected intradermally in the rear footpads with D-BSA in $0.1 \mathrm{ml}$ of PBS to give a total dose of $50 \mu \mathrm{g}$ D-BSA per animal. The animals were skin tested by intradermal injection on both sides of shaved flank with $50 \mu \mathrm{g}$ of BSA in $0.1 \mathrm{ml}$ of PBS. Delayed-type skin reactions (24-hr reactions) were read by measuring the thickness of foci of induration with a dial gauge caliper (Ozaki Seisakusho Co., Tokyo). The results were expressed in the specific increase in skin thickness, i.e., the reading $24 \mathrm{hr}$ after the injection minus that before the injection at the same skin site. The animals were bled by cardiac puncture immediately after measuring the 24-hr reactions. Anti-BSA antibody titers of the sera were determined by passive hemagglutination with $0.5 \%$ suspension of sheep red blood cells conjugated with BSA with chromium chloride (Jandle and Simons, 1957) in microtiter plates.

Figure 1 shows the kinetics of the DTH responses to $\mathrm{D}_{55} \mathrm{BSA}$ (BSA heavily conjugated with the lipid) and $\mathrm{D}_{28} \mathrm{BSA}$ (BSA lightly conjugated with the lipid). Twenty-four-hour skin reaction to BSA and circulating anti-BSA antibody titer were tested every week for 3 weeks after sensitization. When $50 \mu \mathrm{g}$ doses of $\mathrm{D}_{55} \mathrm{BSA}$ were injected into the footpads of guinea pigs, sustained DTH was 


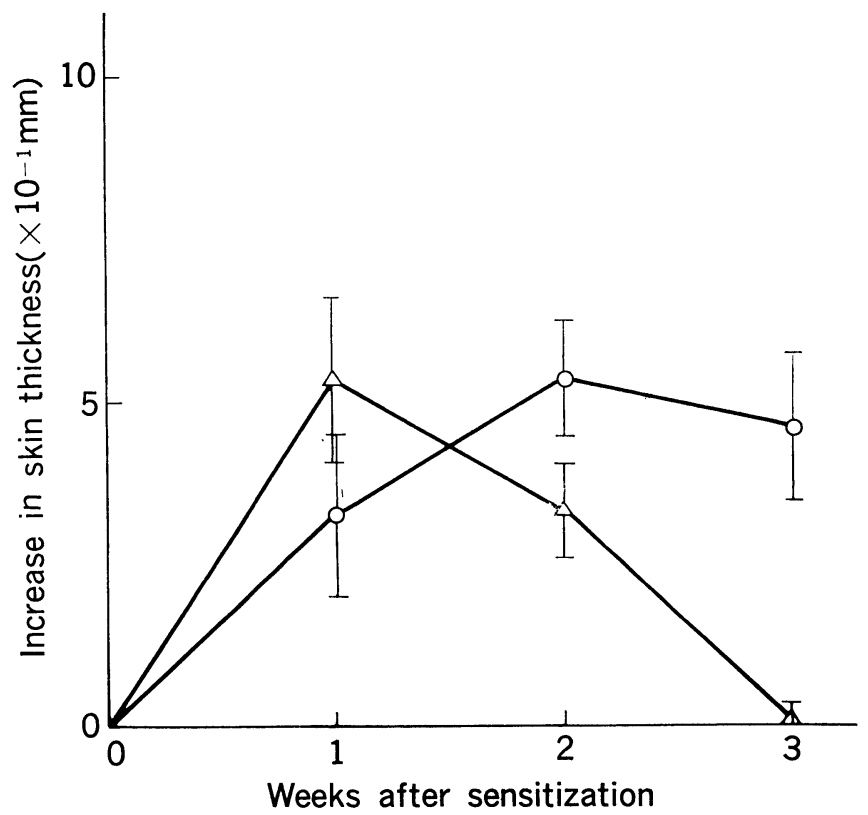

Fig. 1. Kinetics of delayed-type hypersensitipity response after sensitization with $\mathrm{D}_{55} \mathrm{BSA}$, BSA heavily conjugated with dodecanoic acid (-O-) or $\mathrm{D}_{28} \mathrm{BSA}$, BSA lightly conjugated with the lipid $(-\triangle-)$. Groups of five guinea pigs weighing $350 \mathrm{~g}$ were injected with $50 \mu \mathrm{g}$ of $\mathrm{D}_{55}$ or $\mathrm{D}_{28} \mathrm{BSA}$ in PBS. The animals were skin tested by intradermal injection of $50 \mu \mathrm{g}$ of BSA one 2 and 3 weeks after sensitization. The mean increase in skin thickness in $24 \mathrm{hr} \pm$ standard error is shown.

induced; DTH was detected in one week and remained positive for 3 weeks. This is in agreement with the data reported by Coon and Hunter (1973). In another experiment, DTH was detected 10 weeks after sensitization performed under similar conditions (data are not shown). Entirely different kinetics of $\mathrm{DTH}$ was obtained by injection of the same dose $(50 \mu \mathrm{g})$ of $\mathrm{D}_{28} \mathrm{BSA}$. In one week, DTH was observed to a similar level to that induced by $\mathrm{D}_{55} \mathrm{BSA}$. Thereafter, DTH was depressed and disappeared in 3 weeks. Both skin reactions induced by $\mathrm{D}_{55} \mathrm{BSA}$ and $\mathrm{D}_{28} \mathrm{BSA}$ were of typical delayed-type. The reactions were small in $6 \mathrm{hr}$ but became larger with induration and erythema in $24 \mathrm{hr}$. They were not hemorrhagic. No obvious differences were observed between the $\mathrm{DTH}$ reaction induced by $\mathrm{D}_{55} \mathrm{BSA}$ and that by $\mathrm{D}_{28} \mathrm{BSA}$. Histological observations of the skin reaction in $24 \mathrm{hr}$ revealed severe infiltration consisting of predominant mononuclear cells with a minimal number of leukocytes in the dermis even in the center of the reaction focus.

No circulating antibody was detected by passive hemagglutination for 3 weeks after injection of either antigen. Therefore, the depression of DTH induced by BSA lightly conjugated with the lipid does not seem to depend on "blocking" antibodies which have been well documented in tolerance to tumors 


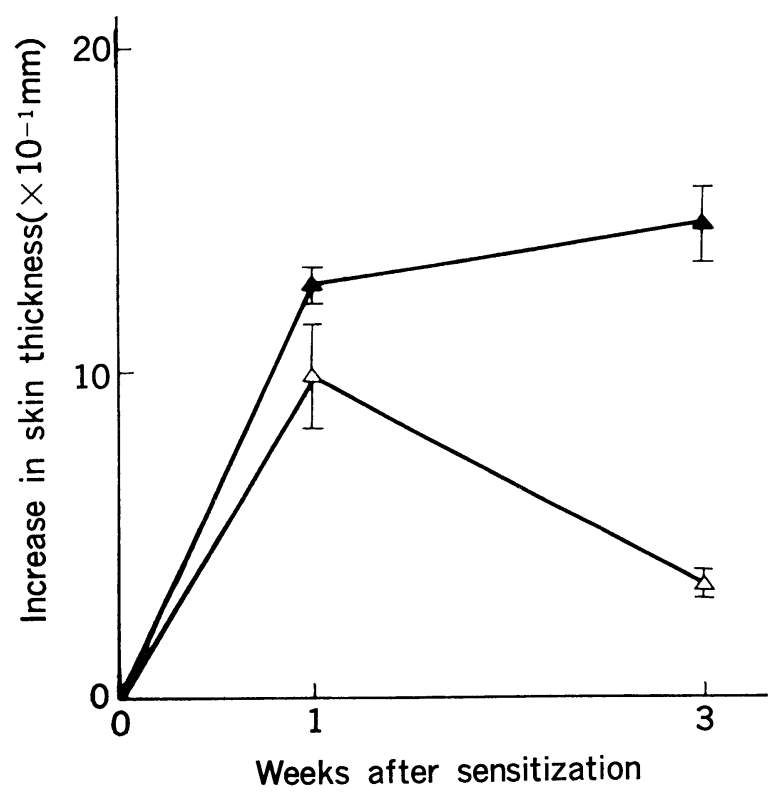

Fig. 2. Effects of the treatment with cyclophosphamide (CY) on the kinetics of delayedtype hypersensitivity response after sensitization with $\mathrm{D}_{34}$ BSA (BSA lightly conjugated with dodecanoic acid). Groups of five guinea pigs weighing 400 to $500 \mathrm{~g}$ were injected intraperitoneally with one dose of CY $(200 \mathrm{mg} / \mathrm{kg})$. Three days later, CY-treated $(-\Delta-)$ or CYuntreated $\left(-\triangle-\right.$ ) animals were injected with $50 \mu \mathrm{g}$ of $\mathrm{D}_{34} \mathrm{BSA}$ in PBS.

The animals were skin-tested with $50 \mu \mathrm{g}$ of BSA one and 3 weeks after sensitization. The mean increase in skin thickness in $24 \mathrm{hr} \pm$ standard error is shown.

and allograft transplants (Hellström, and Alison, 1972; Voison, Kinsky and Duc, 1972) as well as in that to protein antigens (Crowle and $\mathrm{Hu}, 1969$ ). The possibility of depression of DTH mediated by a minimal amount of antibody, however, can not be excluded.

Figure 2 shows the effect of cyclophosphamide (CY, Shionogi Co., Osaka) on the kinetics of transient DTH induced by BSA lightly conjugated with the lipid. GY was injected intraperitoneally in a single dose of $200 \mathrm{mg} / \mathrm{kg} 3$ days before sensitization. The treated and untreated animals were sensitized with $50 \mu \mathrm{g}$ of BSA lightly conjugated with the lipid $\left(\mathrm{D}_{34} \mathrm{BSA}\right)$. The animals were skin tested with $50 \mu \mathrm{g}$ BSA one and 3 weeks after sensitization. In the CYuntreated animals, transient $\mathrm{DTH}$ similar to that induced by $\mathrm{D}_{28} \mathrm{BSA}$ was observed. DTH was demonstrable in one week and became very weak in 3 weeks. In the CY-treated animals, on the other hand, DTH was demonstrated in one week in a slightly higher degree than that in untreated animals and the enhanced response persisted for 3 weeks. Similar enhancement by GY of DTH induced by lipid-conjugated protein (dodecanoyl lysozyme) was observed also in mice in this laboratory (Kojima et al., Unpublished data).

As described above, transient DTH was enhanced by a treatment with CY 
3 days before sensitization and converted into DTH of sustained nature. This result suggests that the transient nature of DTH induced by lightly conjugated D-BSA does not simply depend on a lower extent of stimulation for DTH induction but depends on some suppressive mechanism for DTH.

Suppressor cells in guinea pigs have been reported for DTH of the JonesMote type and contact sensitivity. These cells removed by passing through an anti-guinea pig gamma globulin-column were found to be sensitive to the treatment with GY (Neta and Salvin, 1973, 1974; Katz et al., 1974; Katz, Parker and Turk, 1974, 1975). The treatment with CY is known to deplete B cells in the lymphoid organs in guinea pigs (Turk and Poulter, 1972; Scheper et al., 1975). Suppressor cells similar to those demonstrated in the Jones-Mote type and contact skin reactions might be involved in the transient DTH response described in this paper.

\section{Acknowledgement}

The authors wish to express their appreciation to Prof. Y. Watanabe, Department of Zoology, Tokyo Kyoiku University for his valuable advice. They also thank Mrs. K. Miyanomae for her technical assistance and Miss M. Kimura for her assistance in preparation of the manuscript.

This study was supported in part by a Grant-in Aid for Developmental Scientific Research from the Ministry of Education (No. 057366).

\section{REFERENCES}

Coon, J. AND Hunter, R. (1973): Selective induction of delayed hypersensitivity by a lipid conjugated protein antigen which is localized in thymus dependent lymphoid tissue. J. Immunol., 110, 183-190.

Crowle, A. J. AND Hu, C. C. (1969): Investigation of the mechanism by which "enhancing" antiserum prevents induction of delayed hypersensitivity to protein antigens in mice. $\mathrm{J}$. Allergy, 43, 209-223.

DaIley, M. O. AND Hunter, R. L. (1974): The role of lipid in the induction of hapten-specific delayed hypersensitivity and contact sensitivity. J. Immunol., 112, 1526-1534.

Hellström, I., Hellström, K. E. ANd Alison, A. C. (1971): Neonatally induced tolerance may be mediated by serum-borne factors. Nature, 230, 49-50.

JANDL, J. H. AND Simmons, R. L. (1957): The agglutination and sensitization of red cells by metalic cations: interaction between multivalent metals and the red-cell membrane. Brit. J. Haematol., 3, 19-24.

Katz, S. I., Parker, D., Sommer, G. ANd Turk, J. L. (1974): Suppressor cells in normal immunisation as a basic homeostatic phenomenon. Nature, 248, 612-614.

Katz, S. I., Parker, D. ANd Turk, J. L. (1974): B-cell suppression of delayed hypersensitivity reactions. Nature, 251, 550-551.

Katz, S. I., Parker, D. AND Turk, J. L. (1975): Mechanism involved in the expression of JonesMote hypersensitivity. I. Passive cell transfer studies. Cell. Immunol., 16, 396-403.

Neta, R. AND Salvin, S. B. (1973): Specific depression of delayed hypersensitivity to purified proteins, with relation to production of circulating antibody. Cell. Immunol., 9, 242-250.

Neta, R. AND Salvin, S. B. (1974): Specific suppression of delayed hypersensitivity: The possible presence of a suppressor $B$ cell in the regulation of delayed hypersensitivity. J. Immunol., 113, 1716-1725.

Turk, J. L. And Poulter, L. W. (1972): Selective depression of lymphoid tissue by cyclophosphamide. Clin. Exptl. Immunol., 10, 285-296.

Voison, G. A., Kinsky, R. G. AND Duc, H. T. (1972): Immune status of mice tolerant of living 
cells. II. Continuous presence and nature of facilitation-enhancing antibodies in tolerant animals. J. Exptl. Med., 135, 1185-1203.

Department of Pathology, National Institute of Health, Shinagawa-ku, Tokyo 141, Japan
JOE CHIBA

MINORU OTOKAWA

YASUYUKI EGASHIRA

(Received: July 7, 1976) 